\title{
HIGH-LEVEL PANELS AS DIPLOMATIC INSTRUMENTS: THE AFRICAN UNION PANEL OF THE WISE AND THE EMERGENCE OF AN AFRICAN PEACE DIPLOMACYARCHITECTURE
}

\author{
Jo-Ansie van Wyk ${ }^{1}$
}

\begin{abstract}
High-level panels are institutionalized diplomatic instruments comprising high-profile and respected individuals to address a particular issue. Building on traditional and contemporary institutions in recognizing the Wise or Elderly as diplomats, the African Union Panel of the Wise is one of the five pillars of the African Peace and Security Architecture - and thus peace diplomacy - in terms of Article 11 of the African Union (AU) Protocol establishing the Peace and Security Council. This research analyses the Panel's contribution to African diplomacy by focusing on the Panel's knowledge production; its normative and operational impact; raising awareness and agenda setting; the Panel's innovation in respect of conflict resolution and governance; and the prevention and reduction of conflict in Africa. The research concludes that, despite some contribution to African diplomacy, efforts to prevent and reduce African conflicts have been influenced by the Panel's mandate, processes, and contextual factors. This notwithstanding, the Panel's contribution to an emergent African Peace Diplomacy Architecture is recognised.
\end{abstract}

Keywords: African Union; African Peace Diplomacy Architecture (APDA); diplomacy; high-level panel; preventive diplomacy; Panel of the Wise.

Sleutelwoorde: Afrika-unie; Afrika Vredesdiplomasie-argitektuur (AVDA); diplomasie; hoë-vlak paneel; voorkomende diplomasie; Paneel van die Wyses.

\section{INTRODUCTION}

The Assembly of the African Union (AU) adopted the Protocol Relating to the Establishment of the Peace and Security Council of the African Union (hereafter the Protocol) on 9 July 2002 in Durban, South Africa. Apart from establishing the AU Peace and Security Council (PSC), the Protocol added various other pillars to the African Peace and Security Architecture (APSA). Article 11 of the Protocol, for example, provides for the establishment of one of these pillars, namely a fiveperson Panel of the Wise (hereafter the Panel) to support the initiatives of the PSC

1 Associate Professor, Department of Political Sciences, University of South Africa. E-mail: vwykjak@unisa.ac.za 
and the Chairperson of the AU Commission to prevent conflicts and their escalation on the continent (AU 2002).

The AU is not unique in the appointment and establishment of high-level panels. Similar panels have, for example, been appointed by individual states and multilateral organizations, such as the United Nations (UN), the World Bank and the European Union (EU). However, what distinguishes the AU Panel from the UN and EU panels, for example, is that it contains normative and operational elements of traditional governance and diplomacy on the continent, which contributes, inter alia, to the Panel's sui generis diplomatic practices. In fact, Ambassador Smail Chergui (2014:2), AU Commissioner for Peace and Security, explained that the Panel has been, 'Inspired by the centuries' old practice of African elders' centrality in dispute and conflict resolution in our communities. Indeed, in creating a Panel of the Wise, the AU has in many ways recognised the importance of customary, traditional conflict resolution mechanisms and roles and the continuing relevance of these mechanisms in contemporary Africa."

Scholarship on the diplomatic role, functions and impact of high-level panels in general (Evans 2013), and the Panel specifically, is scant with Gomes Porto and Ngandu (2014:181-206); Jegede (2009:401-433); and Murithi and Mwaura (2010) some of the notable exceptions. In contrast, Africa's security architecture and its security challenges are better documented as, for example, Makinda, Okumy and Mickler (2016), and Kuwali and Viljoen (2014) indicate. Therefore, this contribution aims to add to the literature on African diplomacy and focuses on the Panel as an example of high-level panel diplomacy in general, and African diplomacy in particular, since its inauguration on 18 December 2007. Against the aforesaid, the purpose of the contribution is three-fold. Firstly, the contribution explains the diplomatic utility and significance of high-level panels.

The second objective is to contextualize and analyse the Panel as one of the pillars of APSA, and thus an instrument in the continent's conflict resolution and peace-making efforts, and the emergence of an African Peace Diplomacy Architecture (APDA). In the final instance, the contribution attempts to assess the Panel as an instrument of African diplomacy and, therefore, is limited to a discussion on the Panel, excluding other AU diplomatic instruments such as international commissions, Special Envoys, international contact groups and other AU highlevel panels.

In order to achieve the objectives of the research and for analytical purposes, veteran diplomat Gareth Evans' (2013:278-302) analytical framework to determine the practice, contribution and success of high-level panels as diplomatic instruments is applied in respect of the Panel. Before proceeding to apply this analytical framework, high-level panels as diplomatic instruments are introduced. 


\section{HIGH-LEVEL PANELS AS DIPLOMATIC INSTRUMENTS AND ANALYTICAL FRAMEWORK OF STUDY}

Like bi- and multilateral diplomacy, summitry, and various other adjective diplomacies (defence diplomacy, conference diplomacy etc.), high-level panels, such as the examples in Table 1, are institutionalized and universal modes of diplomatic practice. Typically, high-level panels are diplomatic instruments consisting of internationallyrecognised experts appointed in their personal capacity, rather than as a representative of a government or organisation, and are convened to address a particular issue of international concern independently, with varying levels of operational and normative success (Evans 2013:278). Besides the UN and World Bank, for example, the AU has also appointed several ad hoc high-level panels, such as the High-Level Implementation Panel (AUHIP) on Sudan; the High-level Panel on Darfur; the HighLevel Panel on Côte d'Ivoire; the Panel of Eminent Africa Personalities led by Kofi Annan for Kenya's 2013 elections; and the permanent Panel of the Wise.

Like other international high-level panels, the five-member AU Panel is also composed of internationally-recognised individuals described as, "highly respected African personalities who have made outstanding contribution[s] to the cause of peace, security and development on the continent" (AU 2014a:2). The inaugural Panel (2007-2010) consisted of Salim Ahmed Salim (a former Secretary-General of the Organization of African Unity); Brigalia Bam (the Chairperson of the Independent Electoral Commission of South Africa); Ahmed Ben Bella (a former President of Algeria and Chairperson of the Panel); Elisabeth Pognon (President of the Constitutional Court of Benin); and Miguel Trovoada (a former President of São Tomé and Principé). Similarly ranked individuals, as indicated in Table 2, were appointed to serve on subsequent Panels.

Before introducing the Panel in the next section, Evans' framework (2013:278-302) in the analysis of high-level panels as diplomatic instruments is presented. For Evans (2013:290), high-level panels should add to knowledge; raise awareness of a particular issue; find new ways to address and solve a particular issue; set a credible policy agenda to address and resolve a particular issue; reduce tension or conflict about a particular issue; and contribute to governance. Moreover, a high-level panel should have a clear purpose; an identifiable target audience; and clearly-defined processes, leadership and administrative support to achieve its objectives. Besides these factors, the context of a high-level panel should also be considered. Pertinent to this research, the violent and conflict-ridden context within which the Panel operates should be taken into account. One of the five pillars to APSA, the Panel - the other being the PSC; the Continental Early Warning System (CEWS); the African Standby Force (ASF); and the African Peace Fund (APF) was only initiated in 2007, five years after the establishment of the AU and the adoption of the Protocol in 2002. This had an impact on its development and diplomatic contribution. 
Table 1. A selection of international high-level panels, 1960-2010

\begin{tabular}{|c|c|c|c|c|}
\hline \multicolumn{5}{|l|}{ Security focused } \\
\hline Name & $\begin{array}{c}\text { Initiating or } \\
\text { major sponsoring } \\
\text { government/ } \\
\text { organisation }\end{array}$ & Chair & Report & Year \\
\hline $\begin{array}{l}\text { High-Level } \\
\text { Panel on } \\
\text { Threats, } \\
\text { Challenges and } \\
\text { Change }\end{array}$ & United Nations & $\begin{array}{l}\text { Anand } \\
\text { Panyarachun } \\
+15 \\
\text { panellists }\end{array}$ & $\begin{array}{l}\text { A more secured } \\
\text { world: Our shared } \\
\text { responsibility }\end{array}$ & 2004 \\
\hline \multicolumn{5}{|c|}{ Development focused } \\
\hline $\begin{array}{l}\text { High-Level } \\
\text { Panel for } \\
\text { Financing for } \\
\text { Development }\end{array}$ & United Nations & $\begin{array}{l}\text { Ernesto } \\
\text { Zedillo }+20 \\
\text { panellists }\end{array}$ & $\begin{array}{l}\text { Financing for } \\
\text { Development }\end{array}$ & 2001 \\
\hline \multicolumn{5}{|c|}{ Governance focused } \\
\hline Name & $\begin{array}{c}\text { Initiating or } \\
\text { major sponsoring } \\
\text { government/ } \\
\text { organisation } \\
\end{array}$ & Chair & Report & Year \\
\hline $\begin{array}{l}\text { High-Level } \\
\text { Panel on } \\
\text { United Nations } \\
\text { System-Wide } \\
\text { Coherence }\end{array}$ & United Nations & $\begin{array}{l}\text { Shaukat } \\
\text { Aziz, } \\
\text { Luisa Dias } \\
\text { Diogo, Jens } \\
\text { Stoltenberg + } \\
12 \text { panellists }\end{array}$ & $\begin{array}{l}\text { Delivering as } \\
\text { One: Report of } \\
\text { High-Level Panel } \\
\text { on United Nations } \\
\text { System-Wide } \\
\text { Coherence in } \\
\text { the Areas of } \\
\text { Development, } \\
\text { Humanitarian } \\
\text { Assistance and the } \\
\text { Environment }\end{array}$ & 2006 \\
\hline $\begin{array}{l}\text { High-Level } \\
\text { Commission on } \\
\text { Modernising } \\
\text { the Governance } \\
\text { of the World } \\
\text { Bank Group }\end{array}$ & World Bank & $\begin{array}{l}\text { Ernesto } \\
\text { Zedillo }+10 \\
\text { panellists }\end{array}$ & $\begin{array}{l}\text { Repowering the } \\
\text { World Bankfor } \\
\text { the 21st Century }\end{array}$ & 2009 \\
\hline
\end{tabular}

(Source Evans (2013:280-286)) 
In fact, by the time the AU commemorated its first decade in 2012, the first and second Panels were still in the process of formulating the modus operandi, while also focusing on and supporting renewed AU efforts to resolve the continent's conflicts (Porto Gomes and Ngandu 2014:186-191). These delays, the turn-over of Panel members, little institutional support, and multiple focus areas affected the Panel's operations and credibility, despite the lofty ideals set out in the Protocol.

Table 2. Members of the Panel of the Wise

\begin{tabular}{|c|c|c|}
\hline First Panel & Second Panel & Third Panel \\
\hline Operationalisation & Institutionalisation & Consolidation \\
\hline 2007-2010 & 2011-2013 & 2014-2017 \\
\hline $\begin{array}{l}\text { Ahmed Ben Bella } \\
\text { (Chairperson) }\end{array}$ & $\begin{array}{l}\text { Ahmed Ben Bella } \\
\text { (Chairperson) }\end{array}$ & Luisa Diogo (Chairperson) \\
\hline (Algeria) & (Algeria) & (Mozambique) \\
\hline $\begin{array}{l}\text { Miguel Trovoada (São } \\
\text { Tomé and Príncipe) }\end{array}$ & $\begin{array}{l}\text { Salim Ahmed Salim } \\
\text { (Tanzania) }\end{array}$ & Edem Kodjo (Togo) \\
\hline $\begin{array}{l}\text { Salim Ahmed Salim } \\
\text { (Tanzania) }\end{array}$ & $\begin{array}{l}\text { Mary Chinery Hesse } \\
\text { (Ghana) }\end{array}$ & $\begin{array}{l}\text { Specioza Naigaga Wandira } \\
\text { Kazibwe (Uganda) }\end{array}$ \\
\hline Elisabeth Pognon (Benin) & Kenneth Kaunda (Zambia) & Lakhdar Brahimi (Algeria) \\
\hline Brigalia Bam (South Africa) & $\begin{array}{l}\text { Marie Madeleine Kalala- } \\
\text { Ngoy (Democratic Republic } \\
\text { of the Congo) }\end{array}$ & $\begin{array}{l}\text { Albina Faria de Assis } \\
\text { Pereira Africano (Angola) }\end{array}$ \\
\hline
\end{tabular}

(Adapted from Chergui (2014:1-6); Salim (2014:1); Porto Gomes and Ngandu (2014:181-206))

\section{THE AFRICAN UNION PANEL OF THE WISE}

Several elements, obligations and rights of the Panel are outlined in Article 11 of the Protocol which explains:

- The rationale - "to support the efforts of the Peace and Security Council and those of the Chairperson of the Commission, particularly in the area of conflict prevention";

- The composition and qualifications - "five highly respected African personalities from various segments of society who have made outstanding contribution[s] to the cause of peace, security and development on the continent". A further qualification for members is that they, "shall not hold active political office 
at the time of their appointment and during their tenure as Panel members" (AU 2007:1);

- The appointment - "selected by the Chairperson of the Commission after consultation with the Member States concerned, on the basis of regional representation and appointed by the Assembly";

- tenure - three years;

- $\quad$ responsibility and scope - "advise the Peace and Security Council and the Chairperson of the Commission on all issues pertaining to the promotion, and maintenance of peace, security and stability in Africa";

- modus operandi - "at the request of the Peace and Security Council or the Chairperson of the Commission, or at its own initiative, the Panel of the Wise shall undertake such action deemed appropriate to support the efforts of the Peace and Security Council and those of the Chairperson of the Commission";

- mandate - "to pronounce itself on issues relating to the promotion and maintenance of peace, security and stability in Africa"; and

- $\quad$ report structure - "report to the Peace and Security Council and, through the Peace and Security Council, to the Assembly". Article 11 also provides that the Panel shall meet, "as may be required for the performance of its mandate" (AU 2002).

From this it is clear that the Panel has an advisory and supportive role in respect of the PSC and the Chairperson of the Commission, with little room for pro-active initiatives. The Panel's modalities, and thus its diplomatic involvement, role and practices, are prescribed as the facilitation and establishment of channels of communication; fact-finding missions; shuttle diplomacy between parties; encouraging political dialogue, assisting and advising mediation teams; assisting and advising parties on conflict resolution; and developing and recommending ideas and proposals to promote peace, security and stability. Besides this, the Panel can also make use of personal mediation, diplomacy and good offices to achieve its mandate (AU 2007:2-3).

The Panel has also been invited for consultations by various Heads of State and Government. In 2009, for example, Muammar El Ghaddafi of Libya and AU Chairman at the time invited the Panel for consultations (AU 2009a:2). The Panel's engagement with Libya occurred early in its existence. During Ghaddafi's tenure as AU Chairperson, the Panel was invited to host its sixth meeting in Tripoli. Here it discussed and finalised its Report on the election-related disputes and conflicts. It also "exchanged views" on, amongst others, the situation in Guinea Bissau, Guinea 
and Madagascar; identified "potential conflict situations" on the continent; and took the decision to undertake field missions (AU 2009a:2-3).

Prior to any of these activities, the Panel has to meet five criteria determining its intervention, namely the degree to which a conflict is already receiving regional and international attention; whether the PSC is already involved in resolving the conflict and whether the Panel's involvement may contribute to conflict resolution; the duration of the conflict and the danger of the conflict further escalating, despite mediation and conflict resolution efforts; whether a conflict has suddenly deteriorated; and whether the relevant peace agreement has encountered opposition that is risking a resurgence of the conflict (Majinge 2011:124).

Since its inception, the Panel has been engaged with tense electoral and political processes in Guinea (2010); Egypt and Tunisia in the wake of the Arab Spring; the Democratic Republic of the Congo (DRC) (2011); Senegal (2012); Sierra Leone and Ghana (2012); and Kenya (2013) (Gerenge 2015:3). Whereas the Panel's intervention in Tunisia, for example, produced some results, its intervention in the DRC did not. The Panel delayed its intervention in the DRC in November 2011, with the result that by the time it intervened, the electoral arena was already very tense with election-related violence occurring. This highlights the importance of purpose and timing of these interventions (Gerenge 2015:4).

Despite its wide-ranging modalities, the Panel's functionality has been undermined by its predominantly advisory and supportive role; little institutional support from the AU; and its reactive - rather than proactive - behaviour. Further limitations are due to its slow reaction to crises or potential conflicts as a result of the time it takes to assess the criteria for responding, adding to the Panel's limited role in preventive diplomacy.

Against the background of Article 11 of the Protocol, the remainder of the article attempts to determine the utility, significance and contribution of the Panel as an instrument of the AU and African diplomacy to achieve the objectives of the Union set out in its Constitutive Act.

\section{KNOWLEDGE PRODUCTION, OPERATIONAL AND NORMATIVE IMPACT}

The collection, production and communication of information or knowledge are important elements of diplomacy. Besides this, the most significant contribution of diplomacy in general, and the diplomacy of high-level panels in particular, is the ability to generate new insights and approaches to an unresolved issue; socalled "game-changing ideas" that can prevent the violent eruption or escalation of an issue (Evans 2013:287). Article 11 of the Protocol outlines the role and responsibility of the Panel to support the PSC in conflict prevention; to advise 
the PSC on issues related to the promotion and maintenance of peace, security and stability in Africa; and, at the request of the PSC or the Chairperson of the Commission or unilaterally, undertake action "deemed appropriate" to support the efforts of the PSC and the Chairperson of the Commission (AU 2002). It can, therefore, be deduced that the Panel is obliged to contribute to knowledge production in order to realise its mandate.

For the purpose of this research, four of the Panel's knowledge production instruments - thematic focus areas; reports; horizon scanning; and cooperation with the Continental Early Warning System (CEWS) - are analysed. These knowledge production instruments are complemented by diplomatic field missions, such as fact-finding missions; solidarity visits; and experts' workshops. The Panel has deliberated on the situations in several African states, including the Central African Republic (CAR), Somalia, Mauritania, Guinea, Guinea-Bissau, Madagascar and Zimbabwe. It has also undertaken confidence building missions to South Africa and the CAR (AU 2011a:6). The Panel has visited, for example, Tunisia and Egypt in early 2011 during both states' so-called Arab Spring transitions (AU 2011a:6). In the case of Tunisia, in April 2011 a delegation of the Panel undertook a mission to Tunis to "mark the continued support" of the AU "for the efforts of the authorities and people of Tunisia in the current political transition", and to "identify possible accompanying measures to be taken by the AU" (AU 2011b:1). In these instances, the Panel's diplomatic practice was reactive, rather than proactive, a practice endorsed by the Protocol in Article 11.

Since its inception, successive Panels have identified four so-called thematic focus areas (see Table 3 ) and initiated, commissioned and produced reports on issues pertinent to the promotion and maintenance of peace, security, stability and conflict prevention. Following the electoral violence in Kenya and Zimbabwe in 2008, for example, the PSC requested the Panel to focus on election-related violence and impunity. The Panel reported on this theme with the Report and recommendations on election-related conflicts, which was developed by the Secretariat of the Panel and the AU's Department of Political Affairs. In the Report, the Panel considered the AU's preventative diplomacy and early warning mechanisms; electoral governance and administration; the AU's coordination and electoral assistance; post-election conflict transformation mechanisms; the AU's coordination of electoral assistance and international cooperation and partnership; and strategic interventions by the Panel (Buhungiro 2014:29). The Report was adopted by the AU Assembly of Heads of State and Government in 2009 (AU 2009b:1).

In 2009, the Panel's second thematic focus was on impunity, justice and national reconciliation in response to the International Criminal Court's (ICC) indictment of Joseph Kony (leader of the Lord's Resistance Army) and the application for a warrant of arrest against President Omar al Bashir of Sudan. For 
the Panel, these developments challenged the principle of universal jurisdiction and AU decisions. The Panel convened an experts' workshop in Monrovia, Liberia, in May 2009 to review the draft report in the light of these developments. The final report, Non-impunity, truth, justice, and reconciliation in Africa: Opportunities and constraints, focused on African experiences in respect of impunity; existing AU and international instruments; and the consequences and challenges of international interventions. The report also contained recommendations to the Panel and the AU Commission to improve African instruments of justice and reconciliation (AU 2009d:3-4).

The Panel's third thematic focus was women and children in armed conflict (AU 2009b:3). The choice of this thematic reflection was based on evidence confirming the suffering of women and children, "wherever and whenever there is a breakdown of social order, rule of law and ascendance of violence" (AU 2009c:4), and who are, "often subjected to gender based violence, often becoming the single heads of households, displaced/ refugees in dehumanizing camps" (AU 2009b:3). The Panel attempted to make recommendations to improve the implementation of AU legal instruments on eliminating all forms of violence against women and children during armed conflict. The first draft report was reviewed during an Experts' Workshop in Kinshasa, DRC, in May 2010 (AU 2010a:1). Subsequent to this workshop, the Panel undertook various visits, with the assistance of the AU Commission and a team of (unspecified) experts, to finalise the report for submission to the Ordinary Session of the Assembly in 2011 (AU 2009c:4).

The Panel's recommendations in its report, Preliminary report on mitigating vulnerabilities of women and children in armed conflicts (AU 2010b), covered six areas, namely commitment and ratification; promoting AU institutional coordination; monitoring and documentation; promoting accountability mechanisms; prevention and early warnings; and supporting AU-REC relations (AU 2013a). Based on the Panel's report, the PSC initiated an annual open session on women and children in armed conflicts, as well as the establishment of an AU Peace and Security Gender Mainstream Department and the appointment of the first AU Special Envoy on Women, Peace and Security in 2013 (Buhungiro 2014:29).

The Panel selected political governance for peace, security and stability in Africa in 2011 as its fourth thematic focus. In December 2011, the Panel co-hosted a workshop with the Nairobi-based African Leadership Centre on Strengthening political governance for peace, security, and stability in Africa. Apart from members of the Panel attending this particular workshop, eminent African personalities, such as former presidents Thabo Mbeki, Pedro Pires and Pierre Buyoya, and representatives from regional economic communities (RECs), think tanks and civil society also attended (AU 2011a:2-3). Evidence suggests that the Panel often conducts its business as a result of a request by the PSC (AU 2011a:2-3). 
In fact, the workshop on Strengthening political governance for peace, security, and stability in Africa, took place following a communique of the $275^{\text {th }}$ meeting of the PSC, requesting the Panel to undertake "a comprehensive review" of the existing mechanisms on democratization and governance on the continent (AU 2011a:2-3). The Panel decided to elaborate on the workshop's findings and widely consulted with the Pan-African Parliament, the African Commission on Human and People's Rights, RECs and civil society (AU 2011a:2-3).

Table 3. The Panel's knowledge production, normative and operational impact, 2008-2014

\begin{tabular}{|c|c|c|c|c|}
\hline $\begin{array}{l}\text { Thematic } \\
\text { reflections }\end{array}$ & $\begin{array}{c}\text { Knowledge production } \\
\text { (reports) }\end{array}$ & Status of report & $\begin{array}{c}\text { Normative } \\
\text { impact }\end{array}$ & Operational impact \\
\hline $\begin{array}{l}\text { Election-related } \\
\text { disputes and } \\
\text { conflicts (2008) }\end{array}$ & $\begin{array}{l}\text { Strengthening the Role } \\
\text { of the African Union } \\
\text { in the Prevention, } \\
\text { Management and } \\
\text { Resolution of Election- } \\
\text { related Disputes and } \\
\text { Violent Conflicts in } \\
\text { Africa (2008) }\end{array}$ & $\begin{array}{l}\text { Report and } \\
\text { recommendations } \\
\text { adopted by AU } \\
\text { Heads of States and } \\
\text { Government (July } \\
\text { 2009) }\end{array}$ & $\begin{array}{l}\text { Peacefulness } \\
\text { of elections; } \\
\text { free and fair } \\
\text { elections }\end{array}$ & $\begin{array}{l}\text { Institutionalisation of } \\
\text { pre-election missions }\end{array}$ \\
\hline $\begin{array}{l}\text { Impunity, } \\
\text { justice and } \\
\text { national } \\
\text { reconciliation } \\
\text { (2009) }\end{array}$ & $\begin{array}{l}\text { Non-impunity, } \\
\text { Truth, Justice, and } \\
\text { Reconciliation in Africa: } \\
\text { Opportunities and } \\
\text { Constraints (2009) }\end{array}$ & $\begin{array}{l}\text { AU Transitional } \\
\text { Justice Framework } \\
\text { adopted by PSC } \\
\text { (May 2011) }\end{array}$ & $\begin{array}{l}\text { Transitional } \\
\text { justice }\end{array}$ & $\begin{array}{l}\text { Assembly declared } \\
2014-2024 \text { as the Madiba } \\
\text { Nelson Mandela Decade of } \\
\text { Reconciliation in Africa }\end{array}$ \\
\hline $\begin{array}{l}\text { Women and } \\
\text { children in } \\
\text { armed conflicts } \\
\text { (2010) }\end{array}$ & $\begin{array}{l}\text { Draft Report on Sexual } \\
\text { Violence, Women } \\
\text { and Children in } \\
\text { Conflict Preliminary } \\
\text { report on Mitigating } \\
\text { Vulnerabilities of } \\
\text { Women and Children in } \\
\text { Armed Conflicts }\end{array}$ & $\begin{array}{l}\text { Preliminary report } \\
\text { on Mitigating } \\
\text { Vulnerabilities } \\
\text { of Women and } \\
\text { Children in Armed } \\
\text { Conflicts submitted } \\
\text { to PSC on } 28 \\
\text { March } 2011 \text { (not } \\
\text { yet adopted). To be } \\
\text { deliberated upon by } \\
\text { AU Assembly of } \\
\text { Heads of State in } \\
\text { Addis Ababa }\end{array}$ & $\begin{array}{l}\text { Gender } \\
\text { equality }\end{array}$ & $\begin{array}{l}\text { Mainstreaming of gender } \\
\text { in work of PSC and } \\
\text { contribution to emerging } \\
\text { AU Gender Architecture } \\
\text { Annual briefing to PSC and } \\
\text { annual open PSC sessions } \\
\text { on women and children in } \\
\text { conflict since } 2010 \text {. } \\
\text { Appointment of AU } \\
\text { Special Envoy on Women, } \\
\text { Peace and Security, Bineta } \\
\text { Diop, in } 2014 \text {. } \\
\text { Establishment of AU } \\
\text { Peace and Security Gender } \\
\text { Mainstream Department } \\
\text { Declaration of } 2010-2010 \\
\text { as the Decade of African } \\
\text { Women and appointment } \\
\text { of Committee of } 30 \text { for the } \\
\text { African Women's Decade }\end{array}$ \\
\hline
\end{tabular}


Jo-Ansie van Wyk • High-level panels as diplomatic instruments

\begin{tabular}{|c|c|c|c|c|}
\hline $\begin{array}{l}\text { Thematic } \\
\text { reflections }\end{array}$ & $\begin{array}{c}\text { Knowledge production } \\
\text { (reports) }\end{array}$ & Status of report & $\begin{array}{c}\text { Normative } \\
\text { impact }\end{array}$ & Operational impact \\
\hline $\begin{array}{l}\text { Strengthening } \\
\text { political } \\
\text { governance for } \\
\text { peace, security } \\
\text { and stability in } \\
\text { Africa (2011) }\end{array}$ & $\begin{array}{l}\text { Co-hosted a workshop } \\
\text { on Strengthening } \\
\text { political governance } \\
\text { for peace, security, and } \\
\text { stability in Africa }\end{array}$ & Under review & $\begin{array}{l}\text { Democratic } \\
\text { governance }\end{array}$ & $\begin{array}{l}\text { Contribution to emerging } \\
\text { African Governance } \\
\text { Architecture }\end{array}$ \\
\hline
\end{tabular}

(Adapted from AU (2011a:3); AU (2011c); Salim (2014:5-6); Chergui (2014:2-3); Buhungiro (2014:29); ISS (2015:8))

Besides these thematic foci and reports, the Panel is also producing knowledge in two other ways. Firstly, it conducts so-called horizon scanning, defined as monitoring, reflecting and pronouncing on major current and future peace and security issues by bringing these to the attention of the AU Commission, the PSC and the Assembly (Chergui 2014:2-3; Salim 2014:5). Secondly, the Panel also benefits from, and contributes to the AU's CEWS, one of the pillars of the APSA. The CEWS, based in Addis Ababa, is the AU's collection and analysis capability providing and updating information on potential, actual and post conflict situations to the AU decision-making organs, such as the Panel and AU Special Envoys (Brett 2013:9). The operational impact of this is that the Panel enhances the AU's preventative diplomacy with the Panel Secretariat also serving as the AU Mediation Support Unit, based on data from the CEWS, coordinating the Panel's activities with AU special representatives, special envoys and mediators (Brett 2013:12).

According to one of the Chairpersons of the Panel, Salim Ahmed Salim (2014:5), the prevention of pre-election conflict and disputes remain a "key focus" of the Panel's "direct conflict prevention engagement". Thus, operationally and in support of the norm of free and fair elections, the number of the Panel's pre-election information gathering missions has increased and remains a "considerable" dimension of the work of the Panel (Salim 2014:5). Members of the Panel were deployed in pre-election missions to, amongst others, Egypt, Senegal, Mali, Ghana, Sierra Leone and South Africa (Salim 2014:6). Apart from this operational impact, the Panel's knowledge production has also contributed to some of the AU's Standard Operating Procedures. The Panel has, for example, produced Mediation guidelines and has contributed to an AU "Knowledge Management Framework for Mediation Processes" and the threevolume AU Mediation handbooks (AU 2013b; 2013c; 2013d).

The Panel's knowledge production through thematic focus areas and related reports, have contributed to institutional knowledge and knowledge production, as well as having some normative (free and fair elections; transitional justice; gender equality; and good governance) and operational (institutionalisation of preelection missions; mainstreaming gender; and contributing to an emerging African 
Governance Architecture) impact, as summarized in Table 3. Of these thematic focus areas, women and children in armed conflicts (2010) seems to have produced the most tangible results, namely the mainstreaming of gender in the work of the PSC and its contribution to emerging AU Gender Architecture; annual briefing to the PSC on women and children in conflict since 2010; the appointment of an AU Special Envoy on Women, Peace and Security, Bineta Diop, in 2014; and the establishment of the AU Peace and Security Gender Mainstream Department. While this success may be due to the high representation of women on the Panel compared to other structures of the APSA, it is a necessary step in light of the plight of women on the continent.

Too many reports, however, are drafted and produced by consultants, submitted to the PSC and Commissioner, but never adopted. For example, the Panel admitted that its draft report on election-related violence was produced by "the team of consultants" (AU 2008:1). In this instance, the Panel requested the team of consultants to review the draft report it had prepared on the basis of the recommendations of the Experts' Workshop and the observations made by the members of the Panel (AU 2008:1). The first draft report on impunity, justice and reconciliation was also prepared by a team of consultants (AU 2009c:3-4). Similarly, the first draft report on the thematic reflection, women and children in armed conflicts, was also produced by a "team of [unspecific] experts" (AU 2009c:4). There is thus a need to expand the research and report producing capabilities of the Panel and its Secretariat, rather than outsourcing these functions to consultants.

\section{RAISING AWARENESS AND AGENDA SETTING}

Appointing internationally-recognised individuals for a specific purpose is one of the most significant ways to raise international awareness of a particular issue. The fact that the Panel consists of, "highly respected African personalities who have made outstanding contribution[s] to the cause of peace, security and development on the continent" (AU 2014a:2), as indicated in Table 2, raises awareness of the issues it was mandated to address. Article 11 of the Protocol obliges the Panel to support the PSC and the Chairperson of the Commission's conflict prevention efforts. The Panel's support can thus be requested or initiated and volunteered. Article 11 also requires the Panel to, "pronounce itself on issues relating to the promotion and maintenance of peace, security and stability in Africa" (AU 2002). It can, therefore, be deduced that the Panel can not only raise awareness, but it can also set the agenda on general or particular conflict situations.

The Panel, in terms of the Modalities for the Function of the Panel of the Wise (AU 2007) (hereafter Modalities), is also obliged to facilitate the establishment of channels of communication between the PSC and the Chairperson of the 
Commission; between parties engaged in conflict; carry out fact-finding missions to collect information and raise awareness to prevent conflicts; conduct shuttle diplomacy between parties to a conflict in cases where parties are not ready to engage in formal talks; encourage political dialogue between parties, adopt confidence-building measures, and carry out reconciliation processes and facilitate such efforts; assist and advise mediation teams engaged in formal negotiations; and assist and advise parties on how to resolve disputes related to the implementation of peace agreements (AU 2007:2-3).

Apart from the Modalities (AU 2007), the Panel has also opted to conduct annual thematic reflections "relevant to conflict prevention and/or peace building" in order to "stimulate a policy debate and/or raise awareness" on these themes and "issues relating to the promotion and maintenance of peace, security and stability in Africa" (AU 2009c:3; AU 2014a:2-3); thus contributing to knowledge production, raising awareness and agenda setting. The awareness raising and agenda setting contribution of the Panel has been reflected upon by Smail Chergui (2014:5), AU Commissioner for Peace and Security,

\begin{abstract}
It is my sincere view that enabling the Panel to take action or pronounce itself at its own initiative gives it within the context of APSA the unique ability to have a voice of its own as well as to support, undertake, facilitate and, perhaps more importantly, initiate a variety of different preventive diplomacy measures aimed at on-going disputes. The Panel's continuing support to the Union's Special Envoys, Special Representatives and Mediators should not be underestimated.

In practice, this may include good offices and fact-finding, conciliation and facilitation - as the Panel has, over the years, demonstrated a key number of advantages: the ability to act in confidence and away from media attention; the experience, age and prestige that allows its members to, with authority, intervene to promote dialogue, confidence building and communication and, finally, the capacity building support that the Panel has given to the Union's Special Envoys and Special Representatives.
\end{abstract}

However, the Panel, by its own admission, has "not been able to fully discharge" its responsibilities outlined in the Modalities (AU 2009d:6). This has been ascribed to inter alia, the small size of the Panel (five), limiting the Panel's involvement in and raising awareness of "all the situations warranting its attention" (AU 2009d:6). Moreover, given the high profile of the members of the Panel and their extensive commitments, Panel members are not engaged on a full time basis, often resulting in them not being able to undertake planned missions to resolve tensions, facilitating dialogue among conflicting parties, and creating conditions conducive to the successful implementation of peace processes (AU 2009d:6). 


\section{INNOVATION IN CONFLICT RESOLUTION AND GOVERNANCE}

Evidence suggests that the idea of The Wise, The Elderly, and The Panel as distinguished custodians of wisdom in the African political and conflict resolution context is not novel (Murithi \& Mwaura 2010:79-81; Jegede 2009:411-416). However, this element of the Panel is innovative compared to other international high-level panels. According to the AU (2014b:1) the Panel, "has captured African and international curiosity and imagination because the AU created, at the heart of its decision-making on conflict prevention, management and resolution, an institution inspired by the centuries' old practice of African elders' centrality in dispute and conflict resolution. In creating a Panel of the Wise, the Commissioner noted, the AU has in many ways recognised the importance of customary, traditional conflict resolution mechanisms and roles and the continuing relevance of these mechanisms in contemporary Africa. Independence, experience, maturity, respect - these are but some of the characteristics of Panel members since its inception."

These "customary, traditional conflict resolution mechanisms" (AU 2014b:1) prevail in indigenous traditional and contemporary African societies. Ghana's Constitution, for example, created a Council of State, consisting of distinguished individuals advising the President of Ghana, while the Tindvuna in Swaziland advises the King. In Somaliland, the House of the Elderly and in Burundi, the National Council of Bashingantahea perform similar functions, with a similar institution also present in Ethiopia (House of the Federation) (Jegede 2009:411-416). More recently, RECs have also instituted similar structures in a multilateral context, thus transplanting these national norms to regional governance structures. The Economic Community of West African States (ECOWAS), for example, has established a Council of Elders in 1999, while the Community of Sahel-Saharan States (CEN-SAD) Permanent High Level Mediator for Peace and Security (2000) and COMESA's Committee of Elders (2008) were established later. The Southern African Development Community's (SADC) Mediation Reference Group and Panel of Elders were established in 2010, and the Economic Community of Central African States' (ECCAS) Committee of Ambassadors was established in 2007. Of all the RECs, the Intergovernmental Authority on Development's (IGAD) Mediation Contact Group is yet to be established. The appointment of elderly former African statesmen, such as Joaquim Chissano, Thabo Mbeki and Kofi Annan, to act as mediators and special envoys to address and mediate in some of the continent's conflicts is another illustration of the notion of the elders recognised as political actors, mediators and diplomats in Africa (Jegede 2009:416).

Although the Protocol provided for the establishment of the Panel, it did not expand fully on its operation and mandate. In formulating the Modalities of the Panel, the first members - whose tenure has been described as "creativity and 
discovery" (Salim 2014:4) - contributed not only to the operation and functioning of the Panel (horizontal governance), but also its relations with the PSC and the AU Commissioner (vertical governance). Established in July 2010 by the second Panel to improve its capacity to be more pro-active in "operational prevention", the Friends of the Panel (hereafter Friends), another innovative contribution to international high-level panels, comprises five to ten "eminent African personalities" from various regions (AU 2009d:6-7). As a structure, the Friends was established to support the Panel in its preventative efforts; to undertake visits to potential conflict areas; conduct fact-finding missions; assisting and advising mediation teams; engage in formal negotiations; and assist the Panel in following up on recommendations for the reports of thematic reflections. Moreover, the Friends attend all the meetings of the Panel, as well as enjoy the same privileges as the Panel. Further to this, the Friends can serve as a reservoir to recruit members of the Panel and vice versa, and in this way ensure continuity (AU 2009d:6-7).

During the AU High-level Retreat held in Ouagadougou, Burkina Faso on 4 and 5 June 2012, participants requested the Panel and its regional counterparts to engage African governments on the importance of addressing the underlying causes of conflicts and to develop a specific Institutional Development Policy to strengthen member state institutions to, "put countries on a proper course of conflict prevention and development" (Lamamra 2013:4-5). The Panel and its regional counterparts were also requested to follow-up on their conflict prevention missions to ensure better results, instead of ending with short engagements (Lamamra 2013:4-5). Subsequently, the Panel set out to strengthen its relations with similar mechanisms at REC level (ACCORD 2013). The second Panel, whose tenure was characterized by an expansion of the Panel's activities and of relations with similar regional instruments, in 2012 established the Pan African Network of the Wise (PanWise), consisting of the Panel; their regional counterparts with complementary responsibilities; AU Special Envoys and High-Level Representatives, the Friends, and individual mediators and institutions engaged in mediation activities on the continent (Salim 2014:6).

The Second Retreat of the Panel, attended by the Panel, RECs and other experts, in April 2013 focused on the institutionalization of PanWise and its contribution to Pan-Africanism and the African Renaissance. Besides examining peace and security on the continent, the Retreat also adopted the PanWise Plan of Action (AU 2013e:2). PanWise also supports the work of AU Special Envoys, High-Level Representatives and Mediators through the Panel's Secretariat and has already undertaken several missions, thus illustrating the Panel's increased collaboration and coordination of efforts (Salim 2014:6). The almost simultaneous creation of PanWise and the Secretariat of the Panel signalled the Panel's "full institutionalization" (Chergui 2014:3-4). 
Besides enabling the second Panel to establish and consolidate its partnership with RECs, the Panel also contributed to improving the prevention of and peace-making efforts in African conflicts (Buhungiro 2014:29; AU 2014a:3; Lamamra 2013:3-4). For instance, the Panel has worked "closely" and conducted joint activities with their REC counterparts, with regional panels attending Panel meetings and jointly conducting pre-election assessments and fact-finding missions, such as the Panel's joint mission with COMESA to Egypt (AU 2011d) and Kenya; the joint mission by the Panel, COMESA, ECCAS, SADC and ICGLR to the DRC; and joint missions with ECOWAS to Ghana, Senegal and Sierra Leone; all illustrative of the increased cooperation between the Panel and similar REC mechanisms (AU 2014a:7).

With the establishment of the Secretariat of the Panel, the Panel increased its members' deployment in preventative missions and played a major role in training; capacity-building; knowledge production, among others, to AU Special Envoys, Special Representatives and Mediators; thus acting as a mediation support unit within the Commission. The Panel and its Secretariat also became major actors in the development and organisation of the now traditional Retreat of the AU Special Envoys and Representatives; i.e. the Chairperson of the AU Commission's meeting with all her envoys, mediators, representatives and members of the Panel (Chergui 2014:3-4).

In his reflection on the second Panel, outgoing Chairperson Salim Ahmed Salim (2014:3), explained that the Panel has consolidated itself as an important pillar of the PSC and thus the APSA. Salim also referred to the Panel's "synchronised functioning" within the structures of the AU. Against the aforesaid, it is clear that the Panel has contributed to innovation and governance in respect of international high-level panels with the establishment of the Friends, and PanWise as diplomatic auxiliaries. Therefore, it can be argued that the Panel has also contributed to the establishment of an emerging African Governance Architecture (AGA) and, more importantly, to the establishment of an emerging African Peace Diplomacy Architecture (APDA).

\section{CHALLENGES OF THE PANEL OF THE WISE AND DIPLOMACY IN PRACTICE}

High-level panels are institutionalized ad hoc diplomatic instruments; often with limited results and a limited life-span. The Panel is distinct from typical high-level panels as it does not have a limited life-span; instead its members' tenure is limited. The fact that the AU has identified the Panel as one of the pillars of its peace and security architecture gives it recognition as one of the main diplomatic instruments of the AU, aimed at preventing the escalation of conflicts on the continent 
(Majinge 2011:123-124). This notwithstanding, tension and conflict prevail on the continent.

Very little to no empirical evidence exists on the causal link between the Panel's contribution and the reduction of tension and conflict on the continent. This is one of the main criticisms against the Panel, namely that it has not succeeded in reducing conflict on the continent and that it has not succeeded in preventative diplomacy. In the absence of clear empirical evidence and against the background of the analysis of the Panel's diplomatic contribution, this section focuses on three factors often determining the success of a high-level panel, namely task (mandate), process and context (Evans 2013:290). To this, this study adds a fourth factor: structure.

Firstly, the mandate of the Panel is outlined in Article 11 of the Protocol (AU 2002), which can be linked to Evans' (2013) idea of tasks which includes knowledge production; raising awareness; innovation in conflict resolution; setting a credible policy agenda; reducing tension or conflict about a particular issue; and contributing to governance. Despite the Panel achieving some of Evans' tasks, the Protocol and the Modalities limit the Panel to an advisory and supporting - thus reactive - role. This has resulted in criticism that the Panel is not engaging more situations to prevent conflict (Murithi 2014:146). Apart from its small size (five) and its members' short tenure (three years), the mandate of the Panel is simply too wide; an aspect meant to be addressed by the establishment of the Friends, PanWise and a Secretariat of the Panel. A report on the African Peace and Security Architecture, commissioned by the AU's Peace and Security Department, which was adopted by the Third Meeting of the Chief Executives and Senior Officials of the AU, RECs and Regional Mechanisms (RMs) in 2010, concluded that the mediation role and involvement (direct or indirect) of the Panel should be clarified; that the Panel should be included in the structures of the AU Commission; that the Panel's institutional, human resources and bureaucratic support and the relations between the Panel and RECs should be improved; that dedicated Panel equivalents should be established in RECs; and that the Panel's communication strategy should be improved (Fisher et al. 2010:14). However, to date these recommendations have not been implemented.

In the second instance, process refers to the way a high-level panel operates in terms of its leadership, bureaucratic support and resources; the size and composition of a panel; consultative processes undertaken; branding and packaging of reports and recommendations; and the quality of its advocacy and follow-up (Evans 2013:290). Since its inauguration, the Panel has been led by two Chairpersons, Ahmed Ben Bella (2007-2013) and Luisa Diogo (2014-2017). Ben Bella served two terms in order to ensure continuity. The first Panel was occupied with the establishment and operation of the Panel and its Secretariat (Gomes Porto and Ngandu 2014:181-206). Once this has been achieved, the second Panel 
could expand on its mandate and diplomatic efforts. It was thus during this period (2010-2013) that the Panel increased its knowledge production; achieved normative and operational impact; and improved conflict resolution and governance.

The optimal size set out by Evans for a deliberative high-level panel is 12 to 15 members (Evans 2013:292). The Panel is two to three times smaller. Although the Panel's members are representative of gender, experience, expertise and geography, the small size of the Panel undermines its efficiency and it remains to be seen what the operational impact of the Friends and PanWise would be. These notwithstanding, the Panel has achieved some successes in its consultation and diplomatic processes, including fact-finding missions; experts' workshop; retreats; reports; and briefings to the PSC and the Chairperson of the Commission .

Another aspect related to process is the nature, scope and implementation of the recommendations of a high-level panel. Consisting of individuals with specific qualifications appointed in their personal, rather than public capacity, the Panel is also deemed to be independent and thus relatively free from political interference (Murithi 2014:146). In each of its reports (see Table 3), the Panel has presented numerous - but not always practical - recommendations, but with little traction in terms of implementation (AU 2015:2). In this respect, the Panel has repeatedly called on conflicting parties and states to implement and comply with relevant AU regulations, and to domesticate AU conventions and treaties. One way to overcome this state of affairs is to improve the branding and packaging of the Panel; its activities; reports; and recommendations (Evans 2013:296).

The timing of a high-level panel's engagement is crucial (Evans 2013:298). The very first mission of the Panel - to the CAR - occurred prior to its inauguration in December 2007 (Salim 2014:5), and with very little information and institutional support. The Panel has also been criticized for delaying its response to a crisis, such as during the Libyan crisis. Linked to timing is the type of entry-point chosen, as this may have an impact on the conflicting parties. The Panel, for example, identifies entry-points as fact-finding; solidarity visits; shuttle diplomacy and facilitated dialogues; preventive diplomacy; communication and the role of the Panel's Chairperson and Spokesperson; and the importance of nurturing local and national peace infrastructures, research and knowledge generation (AU 2014b:3).

In respect of process, the diplomatic contribution of a high-level panel also depends on its activities and follow-up once a report has been released (Evans 2013:296). This is, inter alia, due to the fact that the Panel is not as autonomous as it is perceived to be, and does not have the necessary institutional infrastructure. In the case of the Panel, very little of this has been achieved. One exception is the AU Assembly's adoption of the Panel's report, Strengthening the role of the African Union in the prevention, management and resolution of election-related disputes and violent conflicts in Africa, and the Assembly's request to the AU Commission 
to "take all necessary steps" to implement the Panel's recommendations and to report regularly on the progress in the implementation of these recommendations (AU 2009c:3). However, the Preliminary report on mitigating vulnerabilities of women and children in armed conflicts, which was submitted to the PSC on 28 March 2011, has not yet been adopted (ISS 2015:9).

The context within which a high-level panel operates, is a contributing factor to its success and can either be permissive or prohibitive (Evans 2013:290). The Panel has been established relatively recently (2007) and the dynamics and complexities of the continent's conflicts should be taken into account. Since its establishment, the Panel operated in a very tense and conflict-ridden continent; often with states and non-state actors' non-compliance of continental norms and legal provisions, adding to the complexity of the challenges the Panel faces.

A fourth factor determining the contribution of high-level panels as diplomatic instruments is structure or institutional design. The Panel is part of a complex structure, namely the APSA where certain hierarchies occur formally and informally. Due to its advisory and supportive role, rather than decision-making and implementation role, the Panel's authority and influence is lower when compared to other organs of the AU in this hierarchical power structure, and it is further limited by the regular turn-over of Panel members; thus losing institutional memory and personal relations. Moreover, the Panel is also a parallel structure in respect of other APSA structures that have both a pro-active and reactive role; thus affecting the agency of the Panel.

\section{CONCLUSION}

The Panel has, like other international high-level panels, some diplomatic utility and has contributed to knowledge production, with some normative and operational impact that could have been converted into more of this adopted by the AU's decision-making structures. It has also raised awareness on certain issues and set the agenda in respect of these. In using traditional modes of conflict resolution, the Panel is contributing to international innovation in respect of high-level panels and continental efforts of conflict resolution and governance. However, its track record in respect of preventive diplomacy and the reduction of conflict in Africa remains mixed due to various factors, such as the complexity of African conflicts, its limited mandate, and the structure of both the Panel and the APSA.

In conclusion, the Panel has made some contributions to diplomacy in Africa and to high-level panels generally, but perhaps, more importantly, to the Continent's emerging African Peace and Diplomacy Architecture. Despite this, it is time to reconsider the future structure and contribution of the Panel within the continent's APSA and APDA to improve stability and socio-economic development on the continent. 


\section{LIST OF SOURCES}

ACCORD (African Centre for the Constructive Resolution of Disputes) 2013. The African Union Panel of the Wise: Strengthening relations with similar regional mechanisms. A report based on the High Level Retreat of the African Union Panel of the Wise on Strengthening Relations with Similar Regional Mechanisms, held in Ouagadougou, Burkina Faso, on 4 and 5 June 2012, organised by the African Union Peace and Security Department in partnership with the African Centre for the Constructive Resolution of Disputes. Durban: ACCORD.

AU (African Union) 2002. Protocol relating to the establishment of the Peace and Security Council of the African Union. Adopted by the $1^{\text {st }}$ Ordinary Session of the Assembly of the African Union, 9 July, <http://www.au2002.gov.za/docs/summit council/secprot.htm>, accessed 16 July 2015.

AU 2007. Modalities for the functioning of the Panel of the Wise adopted by the Peace and Security Council at its 100th meeting held on 12 November 2007, $<$ https://www.issafrica.org/ uploads/AUPANELMOD.PDF>, accessed 17 July 2015.

AU 2008. Communique. Panel of the Wise. 6th Meeting, 28-29 November. POW/ $P R(I V), \quad<\mathrm{http} / /$ www.peaceau.org/uploads/communique-pofw-28-29-nov.-nairobi. pdf $>$, accessed 24 July 2015.

AU 2009a. Communique. Panel of the Wise fourth meeting, 7 June 2009. POW/PR(VI), $<$ http://www.peaceau.org/uploads/4.-communique-of-the-6th-statutory-mtg-eng-june-6. pdf $>$, accessed 17 July 2015.

AU 2009b. Communique. Seventh Meeting of the Panel of the Wise, 9-10 November, $<$ http://www.pambazuka.net/en/category.php/advocacy/60348>, accessed 17 July 2015.

AU 2009c. Report of the Panel of the Wise on strengthening the role of the African Union in the prevention, management and resolution of election-related disputes and violent conflicts in Africa. Assembly/AU/6(XIII) ANNEX II, < http://www. peaceau.org/uploads/report-on-election-related-disputes-and-conflicts-eng-annexii.pdf>, accessed 27 July 2015.

AU 2009d. Report of the Commission on the activities of the AU Panel of the Wise and the appointment of new members. Assembly of the Union, 15th Ordinary Session, 25-27 July. Assembly/AU/14(XV), <http://www.peaceau.org/uploads/ assembly-au-14-XV-e.pdf>, accessed 24 July 2015.

AU 2010a. Communique of the 8th Meeting of the Panel of the Wise, 21 May, $<$ http://www.peaceau.org/uploads/6.-communiquein-8th-mtg-of-panel-of-the-wiseeng-.pdf $>$, accessed 21 July 2015. 
AU 2010b. Briefing note. Mitigating vulnerabilities of women and children in armed conflicts. PSC/PR/3(CCXXIII), <http://www.peaceau.org/uploads/reportwomen-and-chilren-final-eng-.pdf $>$, accessed 27 July 2015.

AU 2011a. Communique. 11th Meeting of the Panel of the Wise of the African Union, 6-7 December, <http://www.peaceau.org/uploads/communique-11-panel-ofthe-wise-eng.pdf>, accessed 24 July 2015.

AU 2011b. Mission of the Panel of the Wise to Tunisia. Press Statement, 15 April, $<$ http://www.peaceau.org/uploads/communique-panel-of-the-wise-mission-totunisia.pdf $>$, accessed 24 July 2015.

AU 2011c. Strengthening political governance for peace, security and stability in Africa. 4th Thematic Workshop of the African Union Panel of the Wise, 5-6 December, $<$ http://www.fahamu.org/images/AUPoWZanzibarReport.pdf>, accessed 27 July 2015.

AU 2011d. Mission of the Panel of the Wise and the Committee of Elders to Egypt. Press release, 6 June, <http://www.au.int/en/sites/default/files/Communique\%20Panel\%20 of $\% 20$ the $\% 20$ Wise\%20Mission\%20to\%20Egypt-1.pdf>, accessed 27 July 2015.

AU 2013a. Women and children in armed conflict/gender mainstreaming, 22 April, $<$ http://www.peaceau.org/en/topic/women-and-children-in-armed-conflicts-gendermainstreaming $>$, accessed 27 July 2015.

AU 2013b. Managing peace processes. Process related questions. A handbook for AU practitioners. Volume 1. Addis Ababa: AU.

AU 2013c. Managing peace processes. Thematic questions. A handbook for AU practitioners. Volume II. Addis Ababa: AU.

AU 2013d. Managing peace processes. Towards more inclusive processes. A handbook for AU practitioners. Volume II. Addis Ababa: AU.

AU 2013e. The Panel of the Wise to hold its second retreat to examine current challenges to peace and security in Africa. Media Advisory, 11 April, $<\mathrm{http}$ ://au.int/ en/content/panel-wise-hold-its-second-retreat-examine-current-challenges-peaceand-security-africa>, accessed 24 July 2015.

AU 2014a. The Chairperson of the Commission looks forward to working closely with the new Panel of the Wise. Press Release, 9 July, <http://www.peaceau.org/ uploads/auc-com-pow-09-07-2014.pdf>, accessed 24 July 2015.

AU 2014b. Communique. $14^{\text {th }}$ Meeting of the Panel of the Wise, 16-17 September. POW/PR/CMM(XIV), <http://www.fasngo.org/assets/files/Panel\%20of\%20Wise/ communique-the-14th-meeting-panel-of-the-wise.pdf $>$, accessed 24 July 2015. 
AU 2015. Communique. $15^{\text {th }}$ Meeting of the Panel of the Wise, 9 January. POW/PR/ $\operatorname{COMM}(\mathrm{XV}),<$ http://www.peaceau.org/uploads/com-15th-meeting-pow-9-01-2015. pdf $>$, accessed 24 July 2015.

Brett, J 2013. The interrelationship between the African Peace and Security Agenda, the Global Peace and Security Agenda, and regional initiatives, 24 October, $\quad<\mathrm{http} / / / \mathrm{um} . \mathrm{dk} / \mathrm{en} / \sim /$ media/UM/English-site/Documents/Danida/AboutDanida/Danida\%20 transparency/Documents/Grant $\% 20$ committee/2013/Ext\%20 doc/02a\%20Annex\%20A\%20\%20APSA\%20Study.pdf>, accessed 29 July 2015.

Buhungiro, E 2014. "African Union Panel of the Wise”, Conflict Trends 4:27-30.

Chergui, S 2014. Opening Address by Ambassador Smail Chergui, Commissioner for Peace and Security. $14^{\text {th }}$ Meeting of the African Union Panel of the Wise, 16-17 September, <http://www.peaceau.org/en/article/opening-address-by-ambassadorsmail-chergui-commisionner-for-peace-and-security-to-the-14th-meeting-of-theafrican-union-panel-of-the-wise>, accessed 27 July 2015.

Evans, G 2013. "Commission diplomacy". In: AF Cooper, G Heine and R Thakur (eds), The Oxford handbook of modern diplomacy. Oxford: Oxford University Press, pp. 278-302.

Fisher, LM et al. 2010. Africa's Peace and Security Architecture (APSA). 2010 Assessment Study. Report commissioned by the African Union's Peace and Security Department and was subsequently adopted by the 3rd meeting of the Chief Executives and Senior Officials of the AU, RECs and RMs on the implementation of the MoU on Cooperation in the Area of Peace and Security, held from 4-10 November 2010 in Zanzibar, Tanzania, <http://www.securitycouncilreport.org/atf/ cf/\%7B65BFCF9B-6D27-4E9C-8CD3-CF6E4FF96FF9\%7D/RO\%20African\%20 Peace\%20and\%20Security\%20Architecture.pdf>, accessed 21 July 2015.

Gerenge, R 2015. Preventive diplomacy and the AU Panel of the Wise in Africa's electoral-related conflicts. Policy Briefing 136. Johannesburg: South African Institute of International Affairs (SAIIA).

Gomes Porto, J and KY Ngandu 2014. "The African Union, preventive diplomacy, mediation and the Panel of the Wise: Review and reflection on the Panel's first six years", African Security 7(3):181-206.

Herpolsheimer, J 2013. The AU Panel of the Wise and PanWise. University of Leipzig. Unpublished Paper, <http://www.academia.edu/11395446/The_AU_ Panel_of_the_Wise_and_PanWise>, accessed 23 July 2015. 
ISS (Institute for Security Studies) 2015. Peace \& Security Council Report 68, April, <http://www.operationspaix.net/DATA/RAPPORTCPS/47_en $\sim$ v Rapport sur_le_CPS_-_No_68.pdf $>$, accessed 19 November 2015.

Jegede, A 2009. "The African Union peace and security architecture: Can the Panel of the Wise make a difference?", African Human Rights Journal 9(2):401-433.

Kuwali, D and F Viljoen (eds) 2014. Africa and the responsibility to protect. Art 4(h) of the African Union Constitutive Act. Oxon: Routledge.

Lamamra, R 2013. Opening Statement by Ambassador Ramtane Lamamra, Commissioner for Peace and Security. Second Retreat of the Panel of the Wise with similar Regional Mechanisms on the institutionalisation of the Pan African Network of the Wise (PanWise), Addis Ababa, Ethiopia, 11-12 April, <http://www. peaceau.org/uploads/draft-statement-for-the-commissioner-to-the-panwise-addisretreat.pdf>, accessed 27 July 2015.

Majinge, CR 2011. "Regional arrangements and the maintenance of international peace and security: The role of the African Union Peace and Security Council". In: The Canadian Yearbook of International Law 2010, XLVIII. Vancouver: University of British Columbia Press.

Makinda, SM, F Okumu and D Mickler 2016. The African Union. Addressing the challenges of peace, security and governance. New York: Routledge.

Murithi, T 2014. "The Role of the African Peace and Security Architecture in implementation of Article 4(h)". In: D Kuwali and F Viljoen (eds), Africa and the responsibility to protect. Art 4(h) of the African Union Constitutive Act. Oxon: Routledge.

Murithi, T and C Mwaura 2010. "The Panel of the Wise". In: J Gomes Porto and U Engel (eds), Africa's new peace and security architecture. Farnham: Ashgate, pp. 77-90.

Salim, AS 2014. Opening remarks by the outgoing Chairperson of the Panel of the Wise, Dr Salim Ahmed Salim. 14 ${ }^{\text {th }}$ Meeting of the African Union Panel of the Wise, 16-17 September, <http://www.peaceau.org/uploads/opening-remark-by-dr-salim. pdf $>$, accessed 27 July 2015. 